\title{
Role of Performance Appraisal System and Its Impact on Employees Motivation
}

\author{
Pooja Dangol \\ Kathmandu University (KUSOM), Kathmandu, Nepal
}

\begin{abstract}
The general objective of the study is to determine the role of performance appraisal and its impact on employee. The study is guided by the following specific objectives: to establish the extent to which performance appraisal process affects employee motivation, to determine the extent to which appraisers affect staff motivation and to determine the challenges in appraising employee performance. The study adopted descriptive research design. The population of interest consists of 120 employees of Service Industry in Nepal. Data is collected using structured questionnaires and additional qualitative data is collected using the reference from the questionnaire and the objectives of the study. The data is analysed using statistical tools such as frequency distribution, percentages and Pearson correlations. Data is presented using tables and charts. The research findings suggest that regular assessment of performance leads to employee motivation. Performance appraisal rating can be considered as a technique that has a positive effect on work performance and employee motivation. Employees may be motivated if the appraisal process is based on accurate and current job descriptions. On the challenges of performance appraisal on employee motivation established that some managers tend to be liberal or strict in their rating of staff which may affect the employees' motivation. The manager's ability to address the skills gaps can have a significant impact on the employee's motivation. Regular ratings may affect the performance and motivation of the employees. Fair assessment of the employee's performance may enhance their motivation.
\end{abstract}

Keywords: Performance appraisal; motivation; performance; employee development.

\section{Introduction}

With the rapid development and growth of organization, both in terms of its operations as well as the growing needs of the employees, it is quite normal for an organization to want to appraise its employee's performance. Traditionally, performance appraisals are conducted in a timely manner in order assess growth and progress of the employees in their work and job roles. Due to this, it is often linked to employee benefits as well as growth and promotion schemes by the organizations. While many organizations provide benefits or promotions based on the result of these appraisals, most of them unconsciously ignore the crucial connection of these appraisals with employee motivation.

According to Chan \& Lynn (1991), organizational performance criteria should include not only just profitability, productivity, marketing effectiveness, customer satisfaction, but also employee morale. The rationale behind it is simple i.e. employees are the key resources and assets for an organization. An organization becomes successful when its workforce works hard to achieve organizations goals and objectives and subsequently, when the organization becomes successful, it helps its employees to progress in life, career and earnings. To become a successful organization, performance appraisal must be conducted all throughout the year, wherein employee's experience so far, motivation level, growth and development and other factors are reviewed to get a clear picture of his/her performance.

\footnotetext{
* Corresponding author.

E-mail address: pujadngol@gmail.com (Pooja Dangol)
} 
According to Rue and Byars, (2005), performance appraisal is a way of determining and communicating how the employees do their jobs and coming up with a plan for improving the process of carrying out work responsibilities. Performance appraisal process can also be referred to as a procedure for determining employee performance. Performance appraisal is essential as it gives updates on the performance of the employees; it identifies training needs and come up with plans for employee development (Livy, 2007).

Performance appraisal system is usually identified as a critical element for boosting employee motivation (Selvarajan \& Cloninger, 2011). Performance appraisal system is an important drive that looks for better, more accurate, more cost-effective ways for of evaluating job performance and employee motivation. Performance appraisal system is a significant technique aimed at enhancing the performance of the employee in the organization (Vasset, Marnburg, \& Furunes, 2011).

Performance appraisal is often considered one of the most important human resource management (Selvarajan \& Cloninger, 2011), and an effective performance appraisal and management system is an integral part of organization's human resource management effectiveness (Guest 1997 cited in Selvarajan and Cloninger, 2011).

Hodgetts (2002) categorizes a four- step process of the performance appraisal system. Performance appraisal systems comprises of established performance standards, a method of determining individual performance, comparison against standards and an evaluation of performance based on the comparison. The first step of establishing performance standards outlines the employees' job responsibilities. The job standards are set against employees' performance. The second step involves pegging the worker performance (such as traits approach, behavioural approach, ranking methods, alternation ranking, and results methods, productivity measures, 360 degrees' evaluation and Management by Objectives (MBO). Thirdly, there is comparison against standards. At some point, the individual work record it compared with the standards set for the job. Fourth, an evaluation of performance is made pegged on the comparison.

Selvarajan and Cloninger (2008) suggest that some organizations are dissatisfied with their performance appraisal process. This implies that the performance appraisal process is not an appropriate mechanism for addressing employee motivation. But, performance appraisal is considered to be essential to create a positive effect in work environment and improve the quality of service. However, there are a number of issues associated with the performance appraisal process and these include poor design, lack of attention to the organizational culture, and unwillingness to confront issues of poor performance, as well as time pressure.

There are a number of different options concerning who should evaluate an individual employee, and the decision needs to be based on a series of factors. Traditionally, it has been the sole responsibility of managers or supervisors to assess performance. However, other organizational members (such as clients, co-workers and subordinates) can be valuable source of information as they are likely to have exposure to different aspects of an employee's performance. Collecting information from multiple sources can increase the accuracy of performance evaluation (can reduce bias) and increase employee's perceptions of fairness (Vasset, Marnburg, \& Furunes, 2011).

A typical traditional appraisal usually occurs once or twice a year. There would be extended time gaps of months between establishing goals and reviewing them, and objectives that are set upon in the beginning of the year are usually only dragged out during appraisal time (Afriyie, 2009). While performance appraisals provide the perfect opportunity for managers and staff to have one-on-one discussion, it is unfortunately open to biased ratings (Khan, 2013). There is also a tendency to focus on the weaknesses instead of strengths, which tend to create conflicts between manager and staff as well as negative work environment (Okeyo, Mathooko and Sitati, 2010). What organizations do not realize is that skills gaps need to be addressed quickly as it would impact the bottom line. During the performance appraisal process, there are common problems that emerge and they include: bias, stereotyping, halo error, distributional errors, similarity error, the appraisal conflicts, proximity error, contrast error and attribution error.

A successful performance appraisal system must fit the organization. Organizations need to assess the suitability of performance appraisal systems to their own workforce before implementing one that meets their needs (Skarlicki \& Folger, 2007). The primary purpose of an appraisal system is to sieve out those who cannot or would not do the job. It has to be communicated to all involved parties and appropriate support and training should be provided especially to managers conducting such sessions with their staff (Shaw, Delery, Jenkins, \& Gupta, 2008). Employers should also 
take note that performance evaluation is a continuous process and not one that happens only once a year. The best appraisals are a two-way discussion and focus on the employee assessing his own performance and setting goals for improvement. And as best practice, organizations should ensure Key Performance Indicators (KPIs) are well communicated to and clarified with staff, and there are proper benchmarks in place against which staff are assessed. Data collected from appraisals should be used to track the success of recruitment and induction practices.

\section{Methods}

\subsection{Nature and Collection of Data}

The research is descriptive in nature. The study setting of this research study is non-contrived. This research is conducted in the natural environment setting without any external influences or an artificially controlled setting.

As the data for this study will be collected once, the research study is cross-sectional. The unit of analysis for the study is at individual level. The relevant population for the research study is 120 employees of Service Industry in Nepal.

The questionnaire has been split into two sections. The initial section asked questions concerning the general responded information. The second section established the effect of the performance appraisal process on employee motivation. The third section determined the extent to which appraisers affect staff motivation. The fourth section examined challenges in appraising employee performance. A five-point Likert scale and rankings is used (ranging from strongly agree to strongly disagree) to reflect the appropriate levels of measurement necessary for statistical analysis.

\subsection{Data Analysis Methods}

According to Mugenda and Mugenda (2009), descriptive analysis involves a process of transforming a mass of raw data into tables, charts, with frequency distribution and percentages. In this study, the descriptive statistics such as percentages and frequency distribution are used to analyse the demographic profile of the participants. The mean described each variable under performance appraisal system, appraisers and the challenges of the appraisal system. Pearson Correlation is used to determine the relationship between independent and dependent variable. The data is presented using tables and figures to give a clear picture of the research findings at a glance.

\section{Data Analysis and Discussions}

\subsection{Response Rate}

Table 1. Demographic Profile of the Study Variables

\begin{tabular}{llcc}
\hline Variable & Classification of Variables & Frequency & Percent (\%) \\
\hline Gender & Female & 40 & 33.33 \\
Age & Male & 80 & 66.67 \\
& 20-30 years & 58 & 48.33 \\
\multirow{3}{*}{ Years of Association } & $31-45$ years & 54 & 45.00 \\
& 46-60 years & 8 & 6.67 \\
& Less than 1 year & 20 & 16.67 \\
& 2-5 years & 28 & 23.33 \\
& 6-10 years & 27 & 22.50 \\
& 11-15 years & 26 & 21.67 \\
& Above 15 years & 19 & 15.83 \\
\hline
\end{tabular}


Table 1 is indicative of the results which are obtained from the demographic profile. Among the 120 respondents, 66.67 percent are male and 33.33 percent are female. 48.33 percent of the respondents are of 20-30 years, 45 percent are of 31-45 years and 6.67 percent are from 46-60 years. 16.67 percent of the respondents are associated with their respective organisations for less than 1 year, 23.33 percent are associated with 2-5 years, 22.50 percent are associated for 6-10 years, 21.67 percent have served for 11-15 years and 15.83 percent have served for more than 15 years.

\subsection{Effect of Performance Appraisal on Employee Motivation}

Table 2. Effect of Performance Appraisal on Employee Motivation

\begin{tabular}{|c|c|c|c|}
\hline S.N. & Effect of Performance Appraisal on Employee Motivation & Mean & Rating \\
\hline 1 & My performance rating is based on how well I am doing. & 3.16 & 3 \\
\hline 2 & $\begin{array}{l}\text { I am satisfied and motivated with the way appraisal system is used to evaluate } \\
\text { my performance. }\end{array}$ & 3.20 & 5 \\
\hline 3 & There are set standards for my job. & 3.17 & 2 \\
\hline 4 & Employee performance is easy to measure. & 2.94 & 7 \\
\hline 5 & $\begin{array}{l}\text { The most recent ratings I received are based on many activities I am } \\
\text { responsible for at work. }\end{array}$ & 3.97 & 6 \\
\hline 6 & My performance is above average ratings. & 2.75 & 10 \\
\hline 7 & I clearly understand the purpose of performance appraisal process. & 3.14 & 11 \\
\hline 8 & $\begin{array}{l}\text { Performance appraisal identifies performance problems to improve employee } \\
\text { productivity and motivation. }\end{array}$ & 3.08 & 4 \\
\hline 9 & Performance appraisal process encourages co-operation. & 3.56 & 8 \\
\hline 10 & The performance appraisal system has helped improve job performance. & 3.05 & 1 \\
\hline 11 & $\begin{array}{l}\text { I am satisfied with the way the performance appraisal system is used to set my } \\
\text { performance goals for each rating period. }\end{array}$ & 2.77 & 9 \\
\hline
\end{tabular}

The findings indicate that a large proportion of the respondents suggested that their performance rating is based on how well they are doing $(\mathrm{m}=3.16)$. The rating scale method offers a high degree of structure for appraisal and motivation. Similarly, the data collected form the respondents also suggested that they believe performance appraisal system has helped improve job performance at work $(\mathrm{m}=3.05)$. It can be deduced that performance appraisal system is often considered one of the most important factors for employee motivation. This is followed by a large number of respondents who suggested that there are set standards for their job $(\mathrm{m}=3.17)$. The performance standards specify what the worker is supposed to be doing.

A substantial number of the respondents responded that the performance appraisal identifies performance problems to improve employee productivity and motivation $(\mathrm{m}=3.08)$. In addition to it, the findings also suggest that the respondents are satisfied and motivated with the way appraisal system is used to evaluate their performance $(\mathrm{m}=3.20)$. From this, it can be deduced that the appraisal process is accurate according to the current job description and experience which may have a direct impact on the employee's motivation to give their best.

However, the number of respondents who are satisfied with the way these appraisals are used to set the performance goals for each rating period is comparatively less $(\mathrm{m}=2.77)$. Even fewer responses are that the performance is above average ratings $(\mathrm{m}=2.75)$ but on a positive note, the number of respondents who understood the purpose performance appraisal process is comparatively large $(\mathrm{m}=3.14)$.

\subsection{Correlation between the Appraisal System and Employee Motivation}

As significance level is 0.00 which is less than 0.05 , therefore, the findings suggest that there is strong correlation between the satisfaction with the current performance appraisal system and having a set of set standards for the job at $(\mathrm{r}=0.346, \mathrm{p}<0.01)$. 
Table 3. Correlation between Appraisal System and Employee Motivation

\begin{tabular}{|c|c|c|c|c|c|}
\hline & & $\begin{array}{l}\text { My } \\
\text { performance } \\
\text { rating is based } \\
\text { on how well am } \\
\text { doing. }\end{array}$ & $\begin{array}{l}\text { There are set } \\
\text { standards for } \\
\text { my job. }\end{array}$ & $\begin{array}{l}\text { I am satisfied } \\
\text { and motivated } \\
\text { with the way } \\
\text { appraisal } \\
\text { system is used } \\
\text { to evaluate my } \\
\text { performance. }\end{array}$ & $\begin{array}{l}\text { I am satisfied with the } \\
\text { way the performance } \\
\text { appraisal system is used } \\
\text { to set my performance } \\
\text { goals for each rating } \\
\text { period. }\end{array}$ \\
\hline \multirow{2}{*}{$\begin{array}{l}\text { Satisfaction } \\
\text { with the } \\
\text { current } \\
\text { performance } \\
\text { appraisal } \\
\text { system }\end{array}$} & $\begin{array}{l}\text { Pearson } \\
\text { Correlation }\end{array}$ & $-0.24^{*}$ & $0.35^{* *}$ & -0.05 & $-0.21 *$ \\
\hline & $\begin{array}{l}\text { Sig. (2- } \\
\text { tailed) }\end{array}$ & 0.01 & 0.00 & 0.61 & 0.04 \\
\hline
\end{tabular}

**. Correlation is significant at the 0.01 level (2-tailed).

3.4. Effect of Performance Appraisers on Employee Motivation

Table 4. Effect of Performance Appraisers on Employee Motivation

\begin{tabular}{clcc}
\hline S.N. & Effect of Performance Appraisers on Employee Motivation & Mean & Rating \\
\hline 1 & Managers know enough to appraise me. & 3.13 & 6 \\
2 & I doubt whether I get a good appraisal. & 3.15 & 3 \\
3 & Managers set targets more clearly. & 3.12 & 12 \\
4 & The evaluator helps me understand what I need to do to improve my & 3.44 & 1 \\
5 & performance. & 3.10 & 9 \\
6 & My manager discusses regularly my job performance with me. & 3.08 & 4 \\
7 & My work colleagues recognize me when I do a good job. & 3.04 & 7 \\
8 & My manager recognizes me when I do a good job. & 2.70 & 13 \\
9 & My manager plays a significant role in my career development. & 3.34 & 10 \\
10 & The customers recognize me when I do a good job. & 3.26 & 2 \\
11 & My subordinates recognize me when I do a good job. & 3.11 & 8 \\
12 & My manager gives me fair feedback. & 3.60 & 5 \\
13 & My manager/supervisor is highly capable as manager. & 3.10 & 11 \\
& My manager/supervisor has reasonable expectations from my work. & & \\
\hline
\end{tabular}

The findings from the respondents claimed that the evaluator helps them understand what they need to do to improve their performance $(\mathrm{m}=3.44)$. A substantial number of the respondents mentioned that the subordinates recognizes the employees when they do a good job $(m=3.26)$. Subordinate evaluations may give valuable information to improve on the employee's motivation. The findings from the responses also indicate that a number of respondents doubt whether they get a good appraisal at a mean of $(\mathrm{m}=3.15)$. The responses indicated customers recognize employees when they do a good job $(m=3.34$. A few other respondents mentioned that their work colleagues recognize the employees when they do a good job $(\mathrm{m}=3.08)$. Peers or co-workers often know the job of the individual employee better than the supervisor does and they are more directly affected by the employee's actions, either positive or negative.

The respondents also seem to agree that the owner, who personally evaluated the employees is highly capable as an evaluator in evaluating their performance $(\mathrm{m}=3.60)$. This indicates that the respondents believe that the evaluator is 
highly capable of evaluating employee performance. This also plays an important factor which is likely to affect their motivation towards work performance.

On the other hand, only a few number of the respondents agree the evaluator discusses regularly the employee job performance with the employees $(\mathrm{m}=3.10)$. There are certain problems that can occur when mangers or the owners themselves are responsible for employee's evaluation process. A less number of the respondents responded that their direct manager or the evaluator recognizes them when they do a good job $(\mathrm{m}=3.04)$ and very few express that their manager has reasonable expectations from the employee work $(\mathrm{m}=3.10)$.

\subsection{Correlation between Appraisers and Employee Motivation}

Table 5. Correlation between Appraisers and Employee Motivation

\begin{tabular}{llcccc}
\hline & $\begin{array}{l}\text { My work } \\
\text { colleagues } \\
\text { recognize me } \\
\text { when I do a } \\
\text { good job. }\end{array}$ & $\begin{array}{l}\text { Managers set } \\
\text { targets more } \\
\text { clearly. }\end{array}$ & $\begin{array}{l}\text { Managers } \\
\text { know enough } \\
\text { to appraise me. }\end{array}$ & $\begin{array}{l}\text { The customers } \\
\text { recognizes me when } \\
\text { I do a good job. }\end{array}$ \\
\hline $\begin{array}{l}\text { Satisfaction } \\
\text { with the } \\
\begin{array}{l}\text { current } \\
\text { appraisers }\end{array}\end{array}$ & $\begin{array}{l}\text { Pearson } \\
\text { Correlation }\end{array}$ & $-0.22^{*}$ & $-0.23^{*}$ & -0.05 & $-0.29^{* *}$ \\
\hline
\end{tabular}

**. Correlation is significant at the 0.01 level (2-tailed).

As significance level is 0.00 which is less than 0.05 , therefore, the findings suggest that there is a strong correlation between the satisfaction with current appraisers and the customers being recognized for the good job that they do at $(\mathrm{r}=0.292, \mathrm{p}<0.01)$.

\subsection{Challenges in Appraising Employee Performance}

Table 6. Challenges in Appraising Employee Performance

\begin{tabular}{clcc}
\hline S.N. & Challenges in Appraising Employee Performance & Mean & Rating \\
\hline 1 & My manager gives me fair feedback. & 3.10 & 4 \\
2 & My ratings are based on reasonable expectations from my work. & 2.99 & 5 \\
3 & The ratings adequately reflect my performance. & 3.96 & 6 \\
4 & My evaluator is based about my job performance. & 2.86 & 8 \\
5 & My evaluator recognizes me when I do a good job. & 2.85 & 9 \\
6 & My evaluator plays a significant role in my motivation. & 1.76 & 12 \\
7 & I am satisfied with my relationship with manager/supervisor. & 3.34 & 1 \\
8 & My manager/supervisor is highly capable to rate my performance. & 3.10 & 2 \\
9 & The appraisal system does not manage me better. & 3.19 & 3 \\
10 & Performance appraisal reflects objectively my performance. & 2.94 & 7 \\
11 & I receive erroneous feedback on my performance. & 2.92 & 10 \\
12 & The managers have reasonable expectations from my work. & 2.11 & 11 \\
\hline
\end{tabular}

The findings from the response obtained indicate that a large number proportion of the respondents claim that they are satisfied with their relationship with the managers $(\mathrm{m}=3.34)$. It is found out that the managers quickly address the skills gaps which have a significant impact on the employee's motivation. Accordingly, a large number of respondents responded that the managers are capable to rate their performance $(\mathrm{m}=3.10)$. This indicates that errors may occur when the managers use only the last few weeks or month of a rating period as evidence of their ratings of 
others which may affect the performance and motivation of the employees. A significant number of the respondents mentioned that the appraisal system does not manage them better $(m=3.19)$. From this, it can be deduced that the performance appraisal system does not determine how well the employees perform their jobs and motivation.

On the other hand, only a few respondents agreed that the ratings are based on reasonable expectations from their work $(m=2.99)$. The findings from the responses also indicated that quite a few number of the respondents agreed that the evaluators are biased about the employee job performance $(\mathrm{m}=2.86)$. This means that the ratings may not be objective in evaluating the employee's actual performance. Also, fewer respondents agreed that the evaluator recognizes the employees when they do a good job $(\mathrm{m}=2.85)$. A small number of the respondents agreed that the evaluator plays a significant role in employees' motivation $(\mathrm{m}=1.76)$ and only a small proportion of the respondents agree that the managers have reasonable expectations from the respondent work $(\mathrm{m}=2.11)$.

\subsection{Correlation between Solution for Performance Appraisal Problems and Management of Employees}

Table 7. Correlation between Solution and Performance Appraisal Problems

\begin{tabular}{|c|c|c|c|c|c|}
\hline & & $\begin{array}{l}\text { My rater plays } \\
\text { a significant } \\
\text { role in my } \\
\text { motivation. }\end{array}$ & $\begin{array}{l}\text { I am satisfied } \\
\text { with the } \\
\text { performance } \\
\text { appraisal } \\
\text { system that is } \\
\text { used to set my } \\
\text { performance. }\end{array}$ & $\begin{array}{l}\text { The } \\
\text { appraisal } \\
\text { system does } \\
\text { not manage } \\
\text { me better. }\end{array}$ & $\begin{array}{l}\text { My ratings are based } \\
\text { on reasonable } \\
\text { expectations from } \\
\text { my work. }\end{array}$ \\
\hline \multirow{2}{*}{$\begin{array}{l}\text { Satisfaction } \\
\text { with the } \\
\text { current } \\
\text { appraisers }\end{array}$} & $\begin{array}{l}\text { Pearson } \\
\text { Correlation }\end{array}$ & $-0.38^{*}$ & 0.17 & $0.32 * *$ & $-0.21 *$ \\
\hline & $\begin{array}{l}\text { Sig. (2- } \\
\text { tailed) }\end{array}$ & 0.00 & 0.09 & 0.00 & 0.04 \\
\hline
\end{tabular}

**. Correlation is significant at the 0.01 level (2-tailed).

As significance level is 0.00 which is less than 0.05 , therefore, the findings suggest that there is a strong correlation between satisfaction with the solutions for performance appraisal problems and the appraisal system not managing employees better at $(\mathrm{r}=0.315, \mathrm{p}<0.01)$.

\subsection{Findings from Interview}

Qualitative data unlike quantitative data cannot be translated into numbers to decipher the exact data. The data collected have therefore, been coded using a thematic approach to decode and decipher the patterns observed during the interview. As the purpose of the interview is to substantiate the data obtained through the questionnaires collected, only two employees are approached for the interview.

\subsection{Performance Appraisal Process Affects Employee Motivation}

Data reduction is a method through which codes are generated by analysing the themes generated during the interview. The themes of every answer generated are identified and coded accordingly. The codes are generated through these themes. The codes generated are presented as follows:

The findings from the first interview (table 8) indicate the importance of accuracy, fairness in scoring the appraisal, goal setting post appraisal, co-operation between the appraisers and appraise as well as the importance of inclusion of self- development aspect for the employees, as important factors which affect the employee motivation during appraisal. 
Table 8. Coding based on First Interview

\begin{tabular}{ll}
\hline Statements/Themes & Codes \\
\hline "though everyone knows it is being done, not all put value to or understand why it is & Clarity of Purpose \\
necessary" & Fairness in Scoring \\
$\begin{array}{l}\text { "the rating is usually average and done by the boss, so, I don't believe it reflects my } \\
\text { correct appraisal" }\end{array}$ & $\begin{array}{l}\text { Lack of Accuracy } \\
\text { Goal-setting }\end{array}$ \\
$\begin{array}{l}\text { "the appraisal doesn't reflect how I performed in my overall in the past year so setting my } \\
\text { target based on it does not reflect my capacity and potential" }\end{array}$ & Co-operation \\
"should be presence of understanding on both parties" & \\
\hline
\end{tabular}

Table 9. Coding based on Second Interview

\begin{tabular}{ll}
\hline Statements/Themes & Codes \\
\hline "just done for salary increment or setting target for the next year" & Clarity of Purpose \\
$\begin{array}{l}\text { "helped in improving my performance compared to last year as my appraisal is a bit } \\
\text { better" }\end{array}$ & Development of Skill \\
$\begin{array}{l}\text { "helped me identify my weakness when boss talked with me after the appraisal so it has } \\
\text { improved my work rate" }\end{array}$ & $\begin{array}{l}\text { Feedback } \\
\text { Performance } \\
\text { "boss is usually here on site and observes us and sometimes helps us, so though I think }\end{array}$ \\
$\begin{array}{l}\text { the appraisal reflects my performance, I don't think it is entirely accurate" } \\
\text { Co-operation }\end{array}$ \\
\hline
\end{tabular}

The findings from the second interview (table 9) indicate importance on clarity on the purpose of the appraisal, development of the workers, the feedback system, fairness in rating, co-operation, accuracy, performance problem solving and presence of biasness as important aspects that can affect the motivation of the employees during the performance appraisal process.

Table 10. Summarisation of First and Second Interview

\begin{tabular}{|c|c|}
\hline Statements/Themes & Codes \\
\hline $\begin{array}{l}\text { "we know when someone has done their part work properly and when one has failed to } \\
\text { meet their target" }\end{array}$ & Recognition \\
\hline "the targets are set based on the company's target for the year" & $\begin{array}{l}\text { Clarity on Target } \\
\text { Goal-setting }\end{array}$ \\
\hline $\begin{array}{l}\text { "our boss talks to each individual after appraisal to tell about their weakness or what or } \\
\text { how they should do next time to improve themselves" }\end{array}$ & $\begin{array}{l}\text { Feedback and Guidance } \\
\text { Problem Solving } \\
\text { Skill Development } \\
\text { Competent }\end{array}$ \\
\hline "my appraisal is, I think, fair bur I believe I could have gotten better ratings" & Fairness \\
\hline "we all work together and everyone helps each other so I don't think our boss is biased" & $\begin{array}{l}\text { No Biasness } \\
\text { Mutual Respect }\end{array}$ \\
\hline
\end{tabular}


Table 11. Summarisation of First and Second Interview

\begin{tabular}{ll}
\hline Statements/Themes & Codes \\
\hline "ratings are fair but sometimes I think our boss does it based on how we should have \\
$\begin{array}{l}\text { done then rather than what we have done that's why they are mostly around average. I } \\
\text { think he } \\
\text { sometimes expects more from us than we can deliver" }\end{array}$ & $\begin{array}{l}\text { Expectation from } \\
\text { Employees Reflection } \\
\text { on Performance }\end{array}$ \\
$\begin{array}{l}\text { "he is the owner himself and has established this organization. He is very capable and we } \\
\text { respect him. Moreover, he treats us like family not just employees" }\end{array}$ & Mutual Respect \\
$\begin{array}{l}\text { "after appraisal he calls us individually to discuss on our appraisal results. They are very } \\
\text { helpful" }\end{array}$ & Individual Feedback \\
$\begin{array}{l}\text { "the owner helps us and provides guidance but that does not mean we must always } \\
\text { depend on him to improve ourselves and grow our career" }\end{array}$ & Career Development \\
\hline
\end{tabular}

The findings indicate some of the challenges on appraisal system are the expectation of work performance from employees, feedback and career development. The findings indicate the biggest challenge is the expectation the evaluator has from the employees. High expectation can often lead to disappointments when they are not met.

\subsection{Data Display}

The data display is method used to summarize the data and information collected during through qualitative method of data collection. Among the various phrases are used during the interview, some phrases are frequently used. The findings from the interview indicated some of phrases that are used frequently during the interview by the interviewees.

Table 12. Frequently used phrases based on the set objectives of the study

\begin{tabular}{|c|c|c|}
\hline Frequently used Phrases & Frequency & Codes \\
\hline $\begin{array}{l}\text { "the ratings of the appraisals are fair but are do not accurately reflect our } \\
\text { level of performance rather our lack of performance from the expected } \\
\text { level" }\end{array}$ & 4 & Accuracy \\
\hline $\begin{array}{l}\text { "everyone one knows when appraisal is done but not everyone knows } \\
\text { how the ratings are scores or what is the main purpose for it as many } \\
\text { think it's is only for salary increment" }\end{array}$ & 3 & $\begin{array}{l}\text { Clarity of Purpose } \\
\text { and Process }\end{array}$ \\
\hline $\begin{array}{l}\text { "feedbacks are individually given to each and every employee and their } \\
\text { performance during the year is discussed as well" }\end{array}$ & 2 & $\begin{array}{l}\text { Performance } \\
\text { Problem Solving }\end{array}$ \\
\hline $\begin{array}{l}\text { "our weakness and strengths are discussed during feedbacks and during } \\
\text { weekly meetings and guidance is provided if we show our capability and } \\
\text { potential for improvement" }\end{array}$ & 2 & Skill Development \\
\hline
\end{tabular}

The data indicates that among the various factors that affect the motivation of the employee in regards to the appraisal system, the four crucial aspects regarded the employees are accuracy, clarity on purpose and process of the appraisal process, prospect of performance problem solving and skill development.

The interviewees firmly believe that accuracy of the rating and proper understanding of the appraisal system play crucial role regarding employee motivation. If the employees perceive that their appraisals are not accurate and do not 
reflect their actual performance, then it will demotivate them from improving their work performance. Similarly, if they have no idea how the appraisal is done or measured, then even if the appraisals are accurate, they might feel unfairness or inaccuracy in scorings.

The interviewees also perceive that it is important that the post-appraisals process would show prospect in helping the employees to further develop their skills and reach their potentials by providing guidance and help in solving the problems that would help in increasing their ratings in the next appraisal. This would help them in developing themselves and increasing their skills which would help to pave their career path as well. Such prospects are important factors of the appraisal which motivates employees.

Table 13. Frequently used phrases based on the study

\begin{tabular}{lcc}
\hline Frequently used Phrases & Frequency & Codes \\
\hline "everyone is treated like a family member and even the owner as well as & 2 & Mutual Respect \\
managers help the workers in the work so there is no bad relation & & Competence \\
between the employees" & 4 & Lack of Biasness \\
"the owner has a lot of experience and is competent to appraise us" & 3 & \\
"everyone is treated fairly and rated based on their work performance \\
rather than their behaviour, so it is not biased"
\end{tabular}

The data indicates that among the various factors and codes generated, the following are most crucial factors regarded by the employees regarding the second objective. The factors are mutual respect, competence of the appraiser and lack of biasness.

According to the interviewees, the competency of the evaluator is one of the crucial aspect when regarding the motivation of the employees in the appraisal process. This indicated that even appraiser play crucial role in motivating employees through the appraisal process which leads to good cooperation during the appraisal as well other day-to-day activity.

Table 14. Frequently used phrases based on the study

\begin{tabular}{lcl}
\hline Frequently used Phrases & Frequency & Codes \\
\hline $\begin{array}{l}\text { "after every appraisal, all the employees are called individually to } \\
\text { discuss their appraisal results and give constructive feedback on their } \\
\text { performance" }\end{array}$ & 5 & Feedback \\
$\begin{array}{l}\text { "we perform the best we can, but the owner has high expectation from } \\
\text { our work which leads to only average ratings in appraisal" }\end{array}$ & 3 & $\begin{array}{l}\text { Expectation on } \\
\text { Performance }\end{array}$ \\
$\begin{array}{l}\text { "these appraisals indeed provide guidance to our career but this mainly } \\
\text { depends on our work and commitment rather than the appraisal }\end{array}$ & 3 & $\begin{array}{l}\text { Career } \\
\text { Development }\end{array}$ \\
\hline
\end{tabular}

From the data collected through interview and the frequency used, it can be inferred that the provision of feedback is taken as a crucial factor by the employees. The feedbacks are given with the aim to help the employees do better in the next appraisal and perform their work better, however, these are done based on the appraisal results. The interviewees believe that the biggest challenge is that the appraiser has too high expectation from them which has led to only average performance ratings. Due to this, the feedbacks are not as effective as they could have been. These feedbacks also help the employees to develop their skills and pave their career path but to the inaccurate ratings, this has not been as effective as it could have been. 


\subsection{Drawing Conclusion}

From the data analysis, the conclusion can be summarized with the help of the conceptual framework (fig. 1).

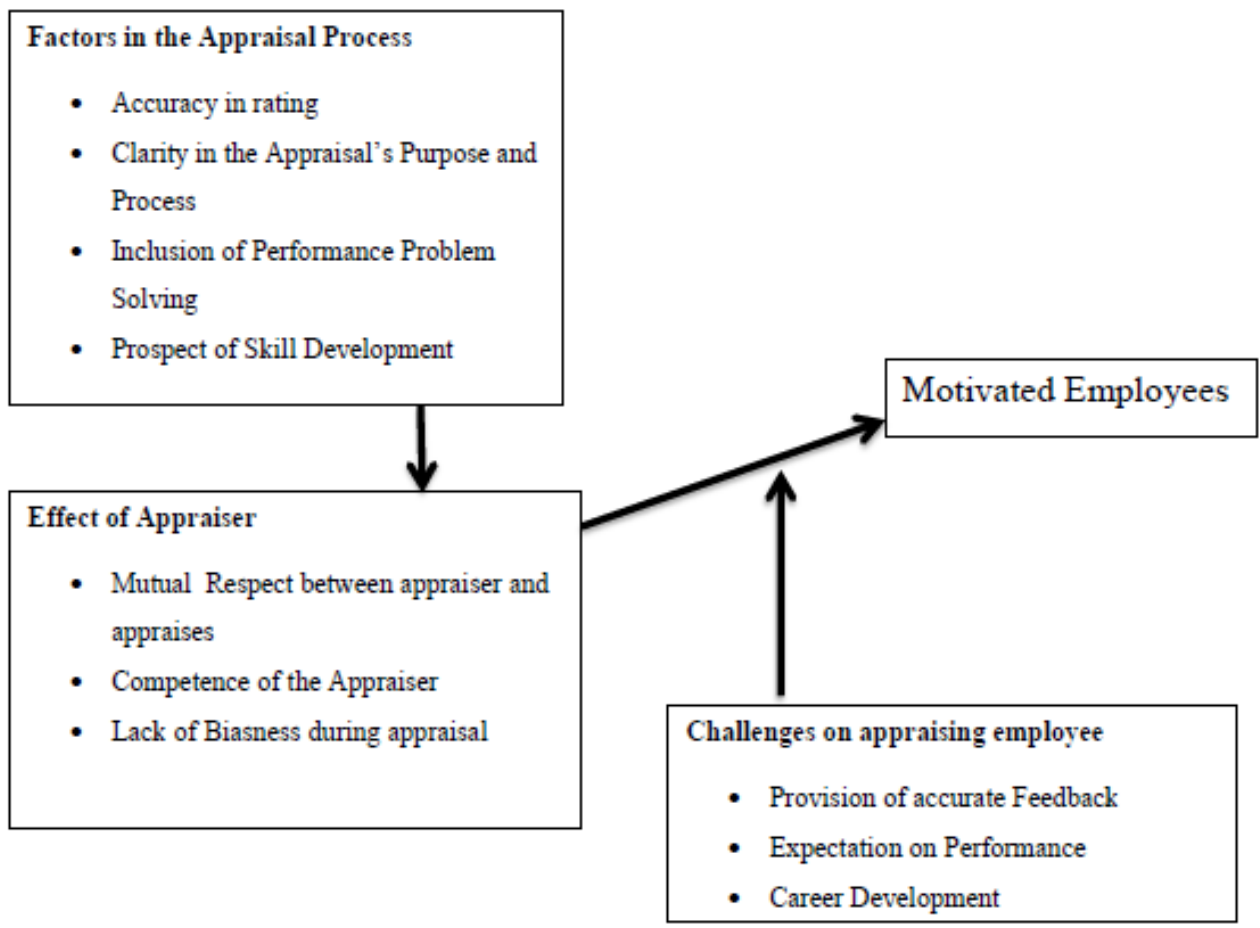

Fig. 1. Conceptual Framework.

\section{Conclusion and Implications}

\subsection{Conclusion}

The general objective of the study is to identify the key variable factors that determine the effect performance appraisal has on the motivation of employees. The study is guided by the following specific objectives: to establish the extent to which performance appraisal process affects employee motivation, to determine the extent to which appraisers affect staff motivation and to determine the challenges in appraising employee performance.

The study adopted descriptive research design. The population of interest consists of 120 employees employed in Service Industry in Nepal. Data is collection using structured questionnaires and open ended interview questions. The data is analysed using the statistical tools such frequency distribution, percentages as well as Pearson correlations. The data is presented using tables and figures.

On the effect of performance appraisal process on employee motivation established that the system is important for employee motivation. Performance appraisal system has helped improve job performance at work. The regular assessment of performance leads to employee motivation. The performance standards are quantified and pegged against an individual evaluation which is essential for employee motivation. Performance appraisal rating can be considered as a technique that has a positive effect on work performance and employee motivation. The employees may be motivated if the appraisal process is based on accurate and current job descriptions. The performance appraisal identifies performance problems to improve employee productivity and motivation. 
On the effect of performance appraisers on employee motivation established that the different evaluators can increase the accuracy of performance evaluation (can reduce bias) and increase employee's perceptions of fairness. Customers can recognize the employees when they do a good job evaluation process that are important for employee's motivation. Subordinate evaluations may give valuable information to improve on the employee's motivation. Peers or co-workers often know the job of the individual employee better than the supervisor does and they are more directly affected by the employee's actions, either positive or negative.

On the challenges of performance appraisal on employee performance established that some managers tend to be liberal or strict in their rating of staff which may affect the employees' motivation. The manager's ability to address the skills gaps can have a significant impact on the employee's motivation. Regular ratings may affect the performance and motivation of the employees. Fair assessment of the employee's performance may enhance their motivation.

Employers should also note that performance evaluation is a continuous process and not one that happens only once a year. The reasonable expectations of the ratings can lead to honest feedback for employee motivation.

\subsection{Implications}

The main objective of the research is to identify the key variable factors that determine the effect performance appraisal has on the motivation of employees. Despite favourable conditions and co-operation from the respondents, there are a few setbacks present.

A major setback is the total population of the respondents. The present research is conducted in limited sample population. It includes 120 employees who work in Service Industry in Nepal. Researchers suggest that less than 100 samples are considered "small sample size," between 100 and 200 samples are considered "medium sample size," and over 200 samples are considered large enough. So the sample size, despite being taken in entirety, is still too small.

Similarly, the study is cross-sectional in nature meaning, the data is gathered only once in order to derive the findings of the research. As questionnaires are involved, there is still possibility of self-biasness from the side of respondents in the data obtained.

There is the need for the researchers to conduct further research on this topic. While working in this research, there are fewer than handful research in existence. Identifying and coming into conclusive on this rising topic will definitely bring a commendable change in the corporate business world.

\section{References}

Anderson, N. R., \& West, M. A. (1998). Measuring Climate for Work Group Innovation: Development and Validation of the Team. Journal of Organizational Behaviour, 235-258.

Caruth, L., \& Humphreys, H. (2008). Performance appraisal: essential characteristics for strategic control. Measuring business excellence, 24-32.

Chan, Y., \& Lynn, B. (1991). Performance Evaluation and the Analytic Hierarchy Process. Journal of Management Articles, 57-58.

Dash, H., Drabman, R., Spitalnik, R., \& Spitalnik, K. (2008). Sociometric and disruptive behavior as a function of four types of token reinforcement systems. Journal of Applied Behaviour Analysis, 93-191.

Denby, S. (2010). The importance of training needs analysis. Industrial and commercial training, 147- 150.

Francis, X., \& Brian, H. (20014). Factors that Bias Employee Performance Appraisals. Work Study, 10-13.

Guest, D. E. (1999). Human Resource Management: The Workers Verdict. Human Resource Management Journal. 
Holzer, N. (2007). The participation-performance controversy reconsidered: Subordinate competence as a mitigating factor. Group and Organization Studies, 411-423.

Islam, R., \& Rasad, S. (2006). Employee Performance Evaluation by the AHP. Asia Pacific Management Review, $163-176$.

Jayawarna, D., Wilson, A., \& McPherson, A. (2007). Training commitment and performance in manufacturing SMEs. Journal of Small Business and Enterprise Development, 14, 321-338.

Jones, H., \& Wright, B. (2007). Perceived organizational support. Journal of Applied Psychology, 500-507.

Kumbhar, V. (2011). Customer's satisfaction in ATM service: An empirical evidence from public and private banks in India. Management Research \& Practices, 24-35.

Lowe, R., \& Vodanovich, S. (2005). A field study of distributive and procedural justice as predictors of satisfaction and organizational commitment. Journal of business and psychology, 99-114.

MacNeil, C. M. (2004). Exploring the supervisor role as a facilitator of knowledge sharing in teams. Journal of European Industrial Training.

Mamoria, C. (2005). Personnel Management. New Delhi, India: Himalaya Publishing House.

Nancarrow, S. A., Booth, A., Ariss, S., Smith, T., Enderby, P., \& Roots, A. (2013). Ten principles of good interdisciplinary team work. Human Resources for Health, 11-19.

Newman, A., Thanacoody, R., \& Hui, W. (2012). The Impact of Employee Perceptions of Training on Organisational Commitment and Turnover Intentions: A Study of Multinationals in the Chinese Service Sector. A Thesis Submitted to Nottingham University Business School. Ningbo, China.

Ngo, H., Turban, D., Lau, C., \& Lui, S. (2005). field study of distributive and procedural justice as predictors of satisfaction and organizational commitment. Journal of business and psychology, 99-114.

Ohabunwa, S. (2009, May 19). Nigeria Business Environment in the New Millennium. A paper presented for HRDB UNILAG on Renovating our corporate management practices for the New Millemium.

Otley, D. (1999). Performance Management: A Framework for Management Control System Research.

Porter, H. (2008). The measurement of organizational commitment. Journal of Vocational Behaviour, 224-247.

Qureshi, M., Ramay, I., \& Zubair, M. (2007). Impact of Human Resource Management (HRM) Practices on Employees Performance. Islamabad: Muhammad Ali Jinnah University.

Rue, L., \& Byars, L. (2005). Management: Skills and Application. Irwin McGraw- Hill 2000.

Scarnati, J. T. (2001). On becoming a team player. Team Performance Management: An International Journal, 7(1/2), 5-10.

Scott, M., Clotheir, B., \& Spriegel, H. (2007). Personnel Management: Principles, practices and point of View. Management of Personnel Journal, 78.

Selvarajan, T., \& Cloninger, A. (2011). Can Performance Appraisals motivate employees to improve performance- A Mexican Study. The International Journal of Human Resource Management, 1- 22.

Shaw, K., \& Ichniowski, C. (2009). The Effect of Human Resource Management Systems on Economic Performance: An International Comparison of US and Japanese Plants. Management Science, 704-721.

Shaw, J., Delery, J., Jenkins, G., \& Gupta, N. (2008). An organization-level analysis of voluntary and involuntary turnover. Academy of Management Journal, 511-525.

Skarlicki, D., \& Folger, R. (2007). Retaliation in the Workplace: The Roles of Distributive, Procedural and Interactional Justice. Journal of Applied Psychology, 434-444. 
Teseema, H., \& Soeters, J. (2006). Affective commitment to the organization: The contribution of perceived organizational support. Journal of Applied Psychology, 825-836.

Tzafir, S. (2005). The relationship between trust, HRM practices and firm performance. International Journal of Human Resource Management, 16-22.

Ubeda, L., \& Almada, C. (2007). Staff development and performance appraisal in a Brazilian research centre. European Journal of Innovation Management, 109-125.

Vasset, F., Marnburg, E., \& Furunes, T. (2011). The effects of performance appraisal in the Norwegian municipal health services: a case study. Human Resources for Health. 